\title{
THE DEVELOPMENT OF COURSEWARE BASED ON MATHEMATICAL REPRESENTATIONS AND ARGUMENTS IN NUMBER THEORY COURSES
}

\author{
Cita Dwi Rosita \\ Department of Mathematics Education, Swadaya Gunung Djati University, Cirebon Indonesia \\ citadwirosita@gmail.com
}

Received: June 30, 2016; Accepted: August 28, 2016

\begin{abstract}
Courseware have an important role in the achievement of the objectives of education. Nevertheless, it does not mean any learning resources can be used for a type of learning. The teacher should provide and develop materials appropriate to the characteristics and the social environment of its student. Number Theory courses is one of the basic subjects that would be a prerequisite for courses at the next level, such as Linear Algebra, Complex Analysis, Real Analysis, Transformation Geometry, and Algebra Structure. Thus, the student's understanding about the essential concepts that exist in this course will determine their success in studying subjects that mentioned above. In trying to understand most of the topics in Number Theory required the abilities of mathematical argumentation and representation. The ability of argumentation is required in studying the topic of complex number system, special operations, mathematical induction, congruence and divisibility. Ability representation especially verbal representations and symbols required by almost all the topics in this course. The purpose of this paper is to describe the development of teaching and learning Number Theory materials which facilitate students to develop the ability of mathematical argumentation and representation. The model used is a Thiagarajan development model consisting phases of defining, planning, development, and deployment. This paper is restricted to the analysis of the results of the materials validation from number theory experts.
\end{abstract}

Keywords: Courseware, Numbers Theory, Argumentation, Representation

\begin{abstract}
Abstrak
Bahan ajar memiliki peranan penting dalam pencapaian tujuan pendidikan. Meskipun demikian, tidak berarti sebarang sumber belajar dapat digunakan untuk suatu jenis pembelajaran. Pengajar hendaknya menyediakan dan mengembangkan bahan ajar yang sesuai dengan karakteristik dan lingkungan sosial mahasiswanya. Mata kuliah Teori Bilangan merupakan salah satu mata kuliah dasar yang akan menjadi prasyarat bagi mata kuliah-mata kuliah keprodian pada tingkat selanjutnya, seperti mata kuliah Aljabar Linear, Analisis Kompleks, Analisis Real, Geometri Transformasi, dan Struktur Aljabar. Dengan demikian, pemahaman mahasiswa secara utuh terhadap konsep-konsep esensial yang ada pada mata kuliah ini akan sangat menentukan keberhasilan mereka dalam mempelajari mata kuliah-mata kuliah tersebut di atas. Dalam memahami sebagian besar topik yang terdapat dalam mata kuliah Teori Bilangan diperlukan kemampuan argumentasi dan representasi matematis. Kemampuan argumentasi diperlukan mahasiswa dalam mempelajari topik sistem bilangan kompleks, operasi khusus, induksi matematika, kekongruenan dan keterbagian. Kemampuan representasi terutama representasi verbal dan simbol dibutuhkan oleh hampir semua topik pada mata kuliah ini. Tujuan penulisan ini adalah untuk mendeskripsikan proses pengembangan bahan ajar Teori Bilangan yang memfasilitasi mahasiswa untuk dapat mengembangkan kemampuan argumentasi dan representasi matematisnya. Model pengembangan yang digunakan adalah model pengembangan Thiagarajan yang
\end{abstract}


terdiri dari tahapan pendefinisian, perencanaan, pengembangan, dan penyebaran. Tulisan ini dibatasi pada analisa penulis terhadap hasil validasi bahan ajar Teori Bilangan dari para ahli.

Kata Kunci: Bahan ajar, Teori Bilangan, Argumentasi, Representasi

How to Cite: Rosita, C.D. (2016). The Development of Courseware Based on Mathematical Representations and Arguments in Number Theory Courses. Infinity, 5 (2), 131-140

\section{INTRODUCTION}

To train students as a problem solver can be done through the giving of the mathematical problems that are not routine to students. When students are faced with a problem which is not routine, indirectly students are practicing how to develop his thinking so hopefully able to utilize and apply mathematical concepts and mathematical thought processes also in solving real-world problems. This is in line with the opinion of Piaget (Suparno, 2001) which states that the exercise of thinking, formulate and solve problems and draw conclusions can help students develop thinking or intelligence.

Previous experience possessed by students in solving problems will affect their ability to solve similar problems. Jonassen (2011) states that one of the factors that affect students' ability to solve problems is prior experience of students. Role of prior experience for a problem solver is as a basis for interpreting the problem, giving signs of what is to be avoided and predict the consequences of a decision or action taken. This is reinforced by the results of research Bereiter \& Miller (Jonassen, 2011) which concluded that the problem solver base the identification of the problem on beliefs about the cause of the symptom ever found.

Based on the above opinion, the author tries to relate it to some concept of Piaget's theory that experience is crucial in the development process of the formation of students' knowledge. The more experience on issues, environment or object faced by students will further develop ideas and knowledge. With more experience, the scheme of students will be a lot challenged and may be developed and modified by the process of assimilation and accommodation.

The development of thought processes that experienced by students when trying to find the right solution is important in learning mathematics. According to Jonassen (2011), in addition to finding an acceptable solution, a problem solver must also be able to recognize similar issues at different times. Previously, Silver \& Marshall (Bergeson, 2000) states that, "while solving mathematical problems, students adapt and extend their existing understanding by both connecting new information to their current knowledge and constructing new relationship within their knowledge structure'. My own interpretation on the statement is that when students solve mathematical problems, then it implies that students are adapting and expanding existing knowledge in a way to connect or associate the new information obtained by previous knowledge thus forming a new information that is interconnected in the structure of knowledge. Fisher (Suryadi, 2012) explains that the success in the thought process that will ultimately affect the development of intelligence a person, determined by the third operation of the acquisition of knowledge (input), the strategy of using the knowledge and problemsolving (output), as well as metacognition and decision making (control ).

If the opinions of the foregoing linked to the quality of students prior knowledge, the authors interpret that in resolving a problem is not only based on the amount of knowledge that has been owned by the students but the quality of the knowledge itself is also a very important 
part. Conceptual framework of the knowledge that has been acquired (prior knowledge) should be better and also integrated, in order to accommodate a variety of perspectives, methods, and solutions through the synthesis process and the conflict in cognitive structure.

A rational from the above statement, there are some specific cognitive abilities that need to be owned by a problem solver, so that he can maximize the knowledge that has been gained and can use it optimally. Novick \& Holyoak (English, 1994), Kaur \& Har (2009), and Polya (Jonassen, 2011) expressed the opinion that is similar to that reasoning analogy have a significant role in solving the problem, because the ability to take advantage of the problems that are known to the new problems that have a structure identical will improve performance in solving the problem. Meanwhile, according to Gentner, Holyoak, \& Kokinov (English, 2004) that, in essence, the analogy lies in the center of human cognition and appears closely linked to the development of the ability of representation.

Having regard to the opinions that have been described above, it can be concluded that the process of solving a mathematical problem is not a simple thought process, the activities require different types of cognitive abilities that are diverse and a complex cognitive activity. The ability to build schema problems, reasoning, arguing and represents knowledge, a cognitive process that allows a student to be able to solve the problem.

Students' ability to identify and represent the same concept through different representations regarded as a prerequisite for understanding certain concepts. The accuracy of the students in constructing various mathematical representations of a problem will make it a much simpler problem of making it easier for students to solve. Conversely, if a representation which is constructed by the students mistakenly then the problem becomes difficult to solve.

At the end of this study, the authors conclude that the ability of argumentation and mathematical representation is an important component in improving the performance in solving the problem. When these activities can be performed optimally and can be developed through the application of mathematics in various contexts, students will grow in a mathematical thinking habits that can help him realize about what they learned. Therefore, the ability of argumentation and mathematical representation will assist students in gaining a deeper understanding. Thus, the students will simultaneously acquire the subject matter of the lecture is are understood and it certainly will improve the effectiveness and efficiency of the learning process and a positive impact on the quality of the process and results of student learning.

Based on the experience of several years to build this course, lack of student learning outcomes is very likely caused by the teaching and learning materials that have not been in accordance with their needs, considering that every student will certainly experience the difference of learning trajectory. Presentation of the material contained in the text book, still can not help the students to learn to understand it comprehensively.

Facts that occurred in Number Theory is learning the abstract concepts causes many examples of the concept cannot be recognized properly by the students. In general, students are not familiar with mathematics learning activities that involve their practice and communicate using various representations and mathematical argument. Such a phenomenon even led to the low quality of student understanding of the Number Theory material. 
Suryadi (2013) explains that the lack of didactic anticipation is reflected in learning planning can be less optimal impact on the learning process for each student. This is due in part to student responses on didactic situation that developed, beyond the reach of lecturers thought or unexplored so the diversity of learning difficulties that arise are not responded appropriately by the lecturers or not responded at all, so the learning processes cannot occur. Therefore it is necessary the development of a teaching and learning materials in Number Theory which is expected to solve the problems mentioned above.

\section{METHOD}

The research was conducted at the Department Mathematics of Education Swadaya Gunung Jati University in Cirebon. This type of research is the Research Development (Research and Development). Model development of teaching and learning materials used is a model developed by Thiagarajan, Semmel, and Semmel (Trianto, 2007) which consists of four phases of development namely Definition, Design, Development, and Deployment.

The purpose of this phases is to produce a draft of learning material that have been revised based on input from the experts. Validation is intended to get input in revising of learning materials that will be tested in the next phases. Validation of learning materials is validation of content and the validation of construct that have been developed at this phases of design. Based on the results of the evaluation by experts, hereafter used as input to improve the instrument before tested. Assessment is done on the instrument and the instrument developed in the design phase (Draft I), resulting a final instrument.

Based on the results of expert validation, revision of learning material (Draft II). Validation of learning materials focused on the content, format, language and illustrations as well as compliance with the learning model that will be used in research. After doing validation, validator to write an assessment of the learning materials. Assessment consists of five categories, ie not good (value 1), poor (2), is quite good (3), good (4) Excellent (5). Data were analyzed by expert judgments based on mean value of the scores. Descriptions of the average scores are shown in Table 1 below.

Table 1 Instrument determining criteria

\begin{tabular}{cc}
\hline Interval & Criteria \\
\hline $1,00 \leq x<1,80$ & not good \\
$1,80 \leq x<2,60$ & poor \\
$2,60 \leq x<3,40$ & quite good \\
$3,40 \leq x<4,20$ & good \\
$4,20 \leq x \leq 5,00$ & Excellent \\
\hline
\end{tabular}

Courseware can be used if the category is "quite good", "good" or "excellent". Overall, phase / flow of learning material development that was done in this study are presented in Figure 1 below. 


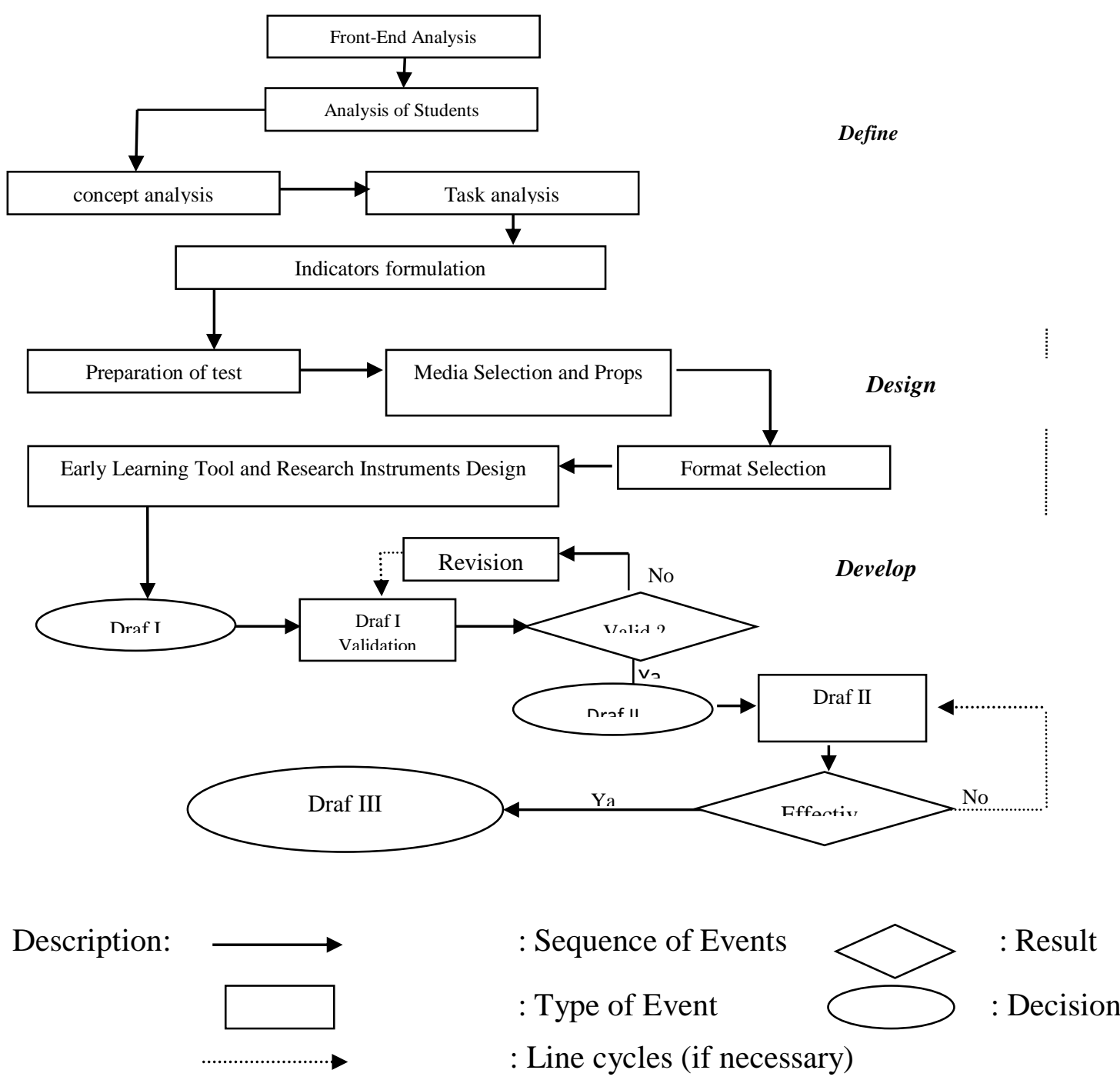

Figure 1. Flowchart modification phases of the development of learning materials with Thiagarajan model

\section{RESULTS AND DISCUSSION}

\section{Results}

Definition phase aims to establish and define the terms of making teaching and learning materials developed by analyzing the goals and learning materials. Activities undertaken in the definition phase includes an analysis of the beginning and the end, the students analysis, concept analysis, task analysis, and formulation of indicators.

The front-end analysis of the study is to determine the basic problems that required in the development of learning instrument. The analysis is done by providing questions from Number Theory courses to students department of mathematics education, Swadaya Gunung Jati University. The aims of the questions is to dig up information on learning obstacles experienced by the students when learning Number Theory. Barriers to learning studied are epistemological. 
Analysis of the student is to examine the characteristics of students accordance with the design and development of teaching and learning materials. These characteristics include cognitive development, academic background, knowledge background.

Analysis of the concept is an identification process that aims to identify, elaborate and systematically compile relevant concepts to be taught. There is a lot of Number Theory material that the concept can be built through previous concepts that have been received by the students. When learning most of the Number Theory topics, students must understand about Real Numbers Systems and the Operations properties of the Real Numbers Set.

The task analysis is done by identifying the major developed academic skills in the development of learning instrument. This analysis was compiled based on competency standards and indicators of achievement of learning outcomes of the Number Theory course. Based on the analysis of the tasks students are expected to meet the specified mathematical argument indicators, namely:

1. be able to assess similarities and differences in the strategies used include identifying the data, warrants and claims;

2. be able to assess the validity of an argument which includes evaluating the claim based on the data and acceptable warrants;

3. can clarify the statement by providing the necessary and sufficient condition;

4. be able to compile an explanation based on the data that is relevant and irrelevant; and

5. can apply the principle to present sufficient data, the relevant warrants, and the acceptable claim in making decisions.

Specified mathematical representation abilities indicators are:

1. can present mathematical problems into a visual model;

2. can connect the procedures and processes at various representations of relevant concepts; and

3. can identify and use objects, processes, and procedures that are appropriate in different representations.

Arrangement of the test of mathematical argumentation and representations ability begins with making of test Lattice. Lattice (test blueprint or table of specification) is the description of the competence and the material to be tested. Lattice test is based on learning objectives that includes a map of the spread of the questions that have been prepared in such a way that the item of the question can be determined with the appropriate level of mathematical arguments and representation completeness of a student.

After arranging the lattice, then made instrument test questions. Instrument test questions that has been prepared, then tested to count validity, reliability, level of difficulty and the distinguishing power. Based on the lattice and analytical validity, reliability, level of difficulty and distinguishing power, then made final test questions instruments.

Media selection tailored to students analysis, task analysis, concept analysis, and facilities available on campus. In this case the media used include: (1) Laptop and LCD, as a medium of learning; (2) student learning material, as the main learning medium for customized learning model that will be used. 
Selection of media is an important part in the learning process because the media will greatly assist the smooth and successful learning process. Therefore, the selection of these media will affect learning formats that will be developed.

Selection format of learning instrument developed in this research tailored to the learning formats that will be developed. Selection of the format related to the learning objectives to be achieved, the learning model used, and specific indicators of the development CIRC learning model based DDR. The format of the selected learning instrument are used to design the content, the selection of learning strategies, and learning resources.

The development phase is to produce a draft of the revised learning instrument based on the input of experts and data obtained from the test.

Validation of experts includes validation of content and construct validation of the courseware that have been developed at the planning phase. Validation is done by five people who are competent to assess the feasibility of a learning instrument. Revisions were made based on advice / instructions from the validator then generates Draft II.

Validator assessment of the courseware is based on the indicators contained in the Validation Sheet courseware. Validator results of the assessment of the draft I courseware can be seen in Table 2 below.

Table 2. Score validator ratings draft I of courseware

\begin{tabular}{ll}
\hline Validator & Score \\
\hline V1 & 3,8 \\
V2 & 3,8 \\
V3 & 3,8 \\
V4 & 3,8 \\
V5 & 4,8 \\
\hline Average & 4,0 \\
\hline Criteria: Good, it can be used with little revision
\end{tabular}

In general, validator stated that courseware can be used with minimal revision. Aspects that need to be more emphasis are the substance of the material, kegrafisan, and special characters according to the CIRC learning model based on DDR. Besides that, the tasks presented in courseware need to pay attention to relevant learning theory. Based on the results of expert validation, some revisions were made to the teaching and learning material can be seen in Table 3 below.

Table 3. Revision of courseware based on the input validators

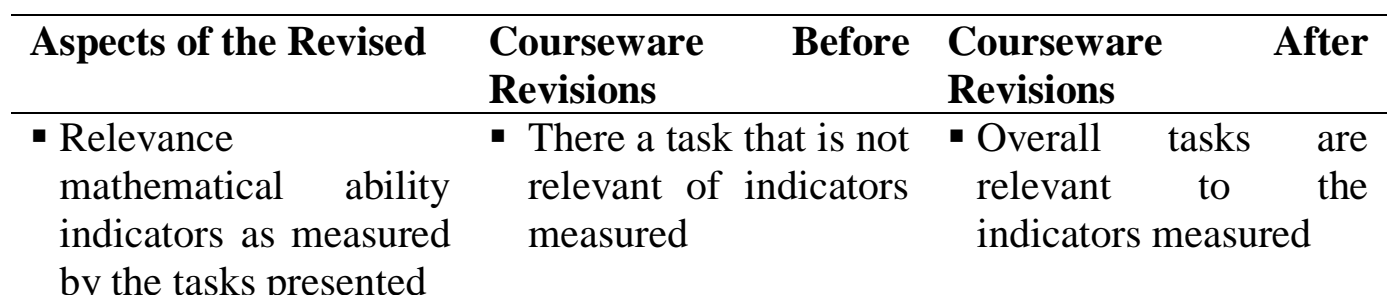




\begin{tabular}{|c|c|c|}
\hline Aspects of the Revised & $\begin{array}{l}\text { Courseware } \\
\text { Revisions }\end{array}$ & $\begin{array}{l}\text { Courseware } \\
\text { Revisions }\end{array}$ \\
\hline - Use of editorial or term & $\begin{array}{l}\text { - There is a term or } \\
\text { editors who have } \\
\text { multiple interpretations }\end{array}$ & $\begin{array}{l}\text { - Change the terms or } \\
\text { editors who have } \\
\text { multiple interpretations }\end{array}$ \\
\hline $\begin{array}{l}\text { - The use of verbal } \\
\text { representation }\end{array}$ & $\begin{array}{l}\text { - Verbal representation } \\
\text { that is used is not } \\
\text { appropriate }\end{array}$ & $\begin{array}{l}\text { - Verbal representations } \\
\text { being used matches }\end{array}$ \\
\hline
\end{tabular}

These aspects are developed on courseware adjusted based on the aspects of the constructivist learning theory as presented in Table 4 below.

Table 4. Aspects of courseware development

\begin{tabular}{|c|c|c|}
\hline \multirow[b]{2}{*}{ Number } & \multicolumn{2}{|c|}{ Courseware } \\
\hline & General Components & $\begin{array}{l}\text { Characteristics } \\
\text { Constructivism }\end{array}$ \\
\hline 1 & $\begin{array}{l}\text { The indicators of achievement of } \\
\text { Competence Standard and Basic } \\
\text { Competence }\end{array}$ & $\begin{array}{l}\text { Presentation of the } \\
\text { prerequisites material }\end{array}$ \\
\hline 2 & $\begin{array}{l}\text { contains learning objectives in } \\
\text { accordance with the Basic } \\
\text { Competence }\end{array}$ & $\begin{array}{l}\text { The presentation of the } \\
\text { subject matter }\end{array}$ \\
\hline 3 & $\begin{array}{l}\text { The suitability of the content with } \\
\text { the aim }\end{array}$ & $\begin{array}{l}\text { transforming } \\
\text { knowledge }\end{array}$ \\
\hline 4 & The truth of concept & presentation of task \\
\hline 5 & Description of concept & $\begin{array}{l}\text { Emphasis social nature } \\
\text { and the Zone of } \\
\text { Proximal Development } \\
\text { on learning materials }\end{array}$ \\
\hline 6 & Exercises of concept support & $\begin{array}{l}\text { Knowledge is } \\
\text { constructed through } \\
\text { cognitive apprenticeship }\end{array}$ \\
\hline 7 & $\begin{array}{l}\text { Utilization of languages effectively } \\
\text { and efficiently }\end{array}$ & $\begin{array}{l}\text { Presentation of the } \\
\text { material with the } \\
\text { principle Scaffolding }\end{array}$ \\
\hline 8 & $\begin{array}{l}\text { Suitability language and level of } \\
\text { development }\end{array}$ & \\
\hline 9 & $\begin{array}{l}\text { Completeness of student books as } \\
\text { learning material }\end{array}$ & \\
\hline
\end{tabular}




\section{Discussion}

Instrument development process begins with preparing the initial draft (Draft I). The draft of the first device was further validated by experts (validator) and made revisions in accordance with the input validators to obtain Draft II.

Revision of the special character of courseware meant that the product produced in accordance with the learning model that will be developed and have special characteristics as the author wish. Explained in Free Writing Subjects that a book will typically contain about something that is a fruit of the mind of an author. If a teacher is preparing a book which is used as teaching and learning material, the mind must be derived from the basic competencies set out in the curriculum, so that the book will give a meaning as courseware for students to learn.

The availability of courseware for students expected to provide facilities in learning each competency to be mastered in order to provide the opportunity for students to learn independently and reduce dependence on the presence of a teacher. Through courseware capable of actively involving intellectual students will make students learn independently trained, guided in constructing new understandings associated with the concept of understanding already exists in students so that their knowledge will be perceived as a science related to each other. Thus the effective learning of communication between teachers and students can be built.

\section{CONCLUSION}

Overall the above discussion shows that the development of courseware in this study have been through the validation phase and the revision until the product is obtained in the form of a final draft of instructional materials that meet the content validity and construct validity. This means that this study has produced a valid courseware.

\section{REFERENCES}

English, L. (1994). Reasoning by Analogy in Constructing Mathematical Ideas. Centre for Mathematics and Sciences Education. Queensland University of Technology.

English, L. (2004). Mathematical and Analogical Reasoning of Young Learners. London: Lawrence Erlbaum Associaties.

Jonassen, D. H. (2011). Learning to Solve Problems. A Handbook for Designing ProblemSolving Learning Environment. NewYork: Routledge.

Kaur, B. \& Har, Y. B. (2009). Mathematical Problem Solving in Singapore Schools. In B Kaur at al (2009). Yearbook. Mathematical Problem Solving. Singapore: World Scientific.

Suryadi, D. (2012). Membangun Budaya Baru dalam Berpikir Matematika. Bandung: Rizqi Press. 
140 Rosita, The Development of Courseware Based on Mathematical Representations ...

Suparno, P. (2001). Teori Perkembangan Kognitif Jean Piaget. Yogyakarta: Kanisius. 